\title{
Stability Problems
}

FOR STOCHASTIC MODELS 

FRONTIERS IN PURE AND APPLIED PROBABILITY, Vol. 3

\section{STABILITY PROBLEMS \\ FOR STOCHASTIC \\ MODELS}

\section{Proceedings of the Fifteenth Perm Seminar}

Perm, Russia, June 2 - 6, 1992

Editors
V. M. Zolotarev, V. M. Kruglov, and V. Yu. Korolev 
TVP Science Publishers

Vavilov st. 42

117966 Moscow GSP-1

Russia

VSP BV

P.O. Box 346

3700 AH Zeist

The Netherlands

(C) 1994 TVP Science Publishers/VSP BV

First published in 1994

ISBN 90-6764-159-6

All right reserved. No part of this publication may be reproduced, stored in a retrieval system, or transmitted in any form or by any means, electronic, mechanical, photo-copying, recording or otherwise, without the prior permission of the copyright owner.

Printed in Russia by Novosti, Moscow 